\title{
Insulating Building Components Made from a Mixture of Waste and Vegetal Materials: Thermal Characterization of Nine New Products
}

\author{
Maria La Gennusa ${ }^{1}$ (D) Concettina Marino ${ }^{2, *(\mathbb{D}}$, Antonino Nucara ${ }^{2} \mathbb{D}$, Maria Francesca Panzera $^{2}$ \\ and Matilde Pietrafesa ${ }^{2}$ \\ 1 Department of Engineering, University of Palermo, Viale delle Scienze, Ed. 8, 90128 Palermo, Italy; \\ maria.lagennusa@unipa.it \\ 2 Department of Civil, Energy, Environmental and Material Engineering (DICEAM), "Mediterranea" \\ University of Reggio Calabria, Via Graziella, Loc. Feo Di Vito, 89122 Reggio Calabria, Italy; \\ antonino.nucara@unirc.it (A.N.); francesca.panzera@unirc.it (M.F.P.); matilde.pietrafesa@unirc.it (M.P.) \\ * Correspondence: concettina.marino@unirc.it
}

check for updates

Citation: La Gennusa, M.; Marino,

C.; Nucara, A.; Panzera, M.F.;

Pietrafesa, M. Insulating Building

Components Made from a Mixture of

Waste and Vegetal Materials: Thermal

Characterization of Nine New

Products. Sustainability 2021, 13,

13820. https://doi.org/10.3390/

su132413820

Academic Editor: Cinzia Buratti

Received: 29 October 2021

Accepted: 9 December 2021

Published: 14 December 2021

Publisher's Note: MDPI stays neutral with regard to jurisdictional claims in published maps and institutional affiliations.

Copyright: (C) 2021 by the authors. Licensee MDPI, Basel, Switzerland. This article is an open access article distributed under the terms and conditions of the Creative Commons Attribution (CC BY) license (https:/ / creativecommons.org/licenses/by/ $4.0 /)$.

\begin{abstract}
Nowadays, energy efficiency and sustainability are the fulcra of building policies. These policies promote the use of new technologies and materials that can reduce the primary energy involved and the environmental costs of construction, guarantying at the same time a high level of comfort for the building's occupants. Synergy between previous construction techniques and the use of new materials should be pursued by employing materials with a low environmental impact and optimal thermal insulation properties. Within this framework, new materials derived from the agriculture sector, and waste or recycling products from the industrial/agricultural sectors have been studied. The aim of this paper is to contribute to this field by analysing the insulation properties of new environmentally friendly materials composited from waste or vegetal products for their applications within the construction sector. Measurements of the thermal conductivity of nine different samples are carried out, obtaining promising results suggesting that these products can be used as feasible alternatives to the materials traditionally used for construction and insulation. However, further analyses are certainly recommended, to assess the samples' structural properties and the influence of pre-treatments on the samples.
\end{abstract}

Keywords: thermal conductivity measurements; building envelope sustainability; waste material; vegetal material; environmentally friendly composites

\section{Introduction}

Nowadays, issues regarding climate change and environmental impact are central in the norms of every country [1]. Among the major emissive sectors, buildings play a fundamental role, being responsible for $40 \%$ of total final energy consumption and $36 \%$ of $\mathrm{CO}_{2}$ emissions globally [2-4]. Moreover, additional pollutant emissions are linked not only to the management of buildings but also to how they are built [5], considering their impact on the environment in the short and long term during their complete life cycle [6-8]. The construction sector has a pivotal role within this framework, due to its high potential to reduce pollutant emissions.

Many European strategies and local norms [9,10] focus on specific objectives and goals in which buildings represent a central pillar of the transition towards the so-called Industry 4.0 [11-13], proposing the concept of a circular economy: a society without waste, where recycling and reusing are the bases to obtain net-zero emissions.

Such issues have led, in recent years, to the use of new materials in the construction sector to create eco-compatible buildings. These buildings are characterized both by a low environmental impact and high indoor comfort for occupants, thanks to their good thermo-physical properties and low embodied energy [14]. 
These new materials are mainly natural or waste materials, which are abundant and do not require sophisticated processes to be produced. Many experiments have already tested natural or waste materials, including bamboo [15,16], bio-based materials [17], mineral wool [18], coffee [19], cardboard [20], and many others, furthering research on their insulation properties and their benefits within the construction sector. Other materials come from agricultural waste [21-24] or waste-recycling processes [25,26].

To guarantee the performance of these new materials in buildings, many of them have been certified by different entities, such as the LEED protocol (Leadership in Environmental and Energy Design [27]) or the BREEAM (Building Research EstablishmentEnvironmental Assessment Method [28]) protocol for sustainable construction. According to these protocols, every structure is considered as one system that has to be globally certified from an environmental and sustainable point of view. Within global norms, a transition towards these materials is also occurring [29], due to the increased attention given to energy efficiency and thermal insulation.

For these reasons, innovative structures have been created, introducing products such as vacuum insulation panels, gas-filled panels, aerogels, phase change materials, etc. [30,31]. Although these insulating materials can lead to significant energy savings when installed in buildings [32], their global environmental impact must be considered, including the energy and materials used in their production [33,34], the pollutant emissions from manufacturing [35,36], and the climatic conditions of the site of use [37].

Nevertheless, the most important aspect of using either natural or waste materials is the opportunity to replace commonly used building materials, which release emissions during their production, management, and disposal, with the feasible alternative of byproducts. In fact, these by-products, made of waste or natural materials, can be found closer to the construction site, reducing transport costs and emissions, and have high environmental compatibility compared to traditional materials, which require a high quantity of energy for their production.

Of course, these types of materials present some limits, such as their costs [38,39], their strong dependence on factors such as humidity or porosity [40,41], and their structural weakness (compared to concrete) [42]. All these aspects are considered in applications of the Life Cycle Analysis (LCA) [43,44], observing the advantages and eventual disadvantages of such materials.

Within this framework, the aim of this paper is to conduct an experiment using new types of biocompatible composites derived from the vegetal sector or from ecological or recycling waste, analysing their thermal and insulation properties. These characteristics are studied through thermal conductivity measurements on nine samples, assembled using a natural binder (a paste of hydraulic lime NHL 3.5 and water) and an environmentally friendly material with different mass compositions. The results are then compared considering their global properties, such as water content, density, and availability.

\section{Methodology}

The first step of the following analysis regards the selection of the involved materials, determining the best pre-treatment for each of them, and how to prepare the paste.

\subsection{Measurement Procedure}

To measure thermal conductivity, different methods can be used: in situ measurement [45] or lab measurement [46-49].

In this study, the measurements were carried out at lab scale, using a heat flow meter (HFM) (Figure 1) to measure the steady heat transfer through flat materials according to ASTM Standard C518-17 [50] and EN 12667 [51]. 


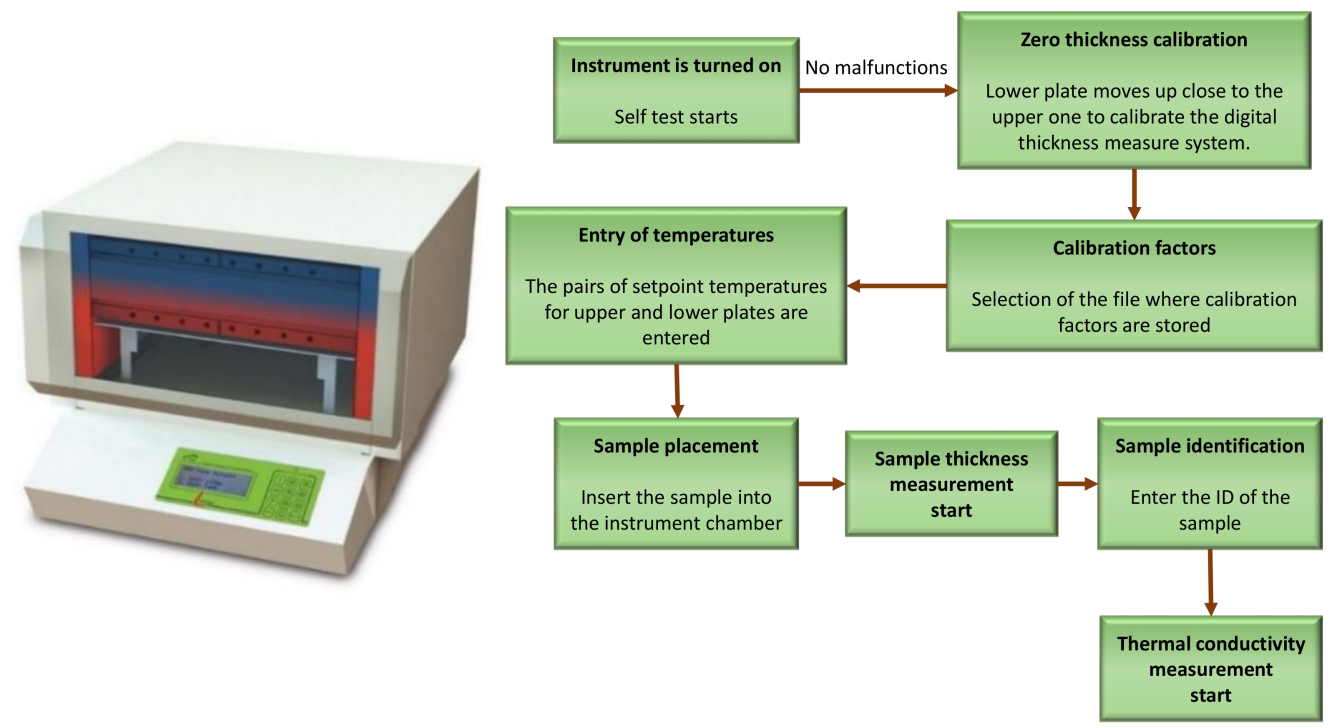

(a)

(b)

Figure 1. (a) HFM instrument; (b) Scheme of the test procedure.

The instrument (FOX $314^{\mathrm{TM}}$ ) is composed of a thermally insulated measure chamber with two heat sinks (upper and lower), set to different temperatures to create a fixed gradient $\Delta \mathrm{T}$. In this way, thanks to the presence of a linear gradient guard to prevent edge heat losses through the limited area of the sample [52], a one-dimensional heat flow inside the chamber occurs.

The two heated/cooled plates (lower and upper) are kept at precise temperatures by two arrays of solid-state (Peltier) elements, which enable the plates to reach the set-point temperatures faster.

To dissipate the heat produced, the metal horizontal plates need to be cooled. This waste heat is removed by a water-cooling system, put on the backside of the Peltier elements, and a recirculating chilling system.

To constantly monitor the plate temperatures and keep the thermal equilibrium of the system, a set of thermocouples is required too, put in contact with the surface of the sample. Close to them, transducers are installed, which are necessary to determine the heat flow together with an algorithm for temperature control.

Thermal conductivity must be measured in steady state conditions, reached only when the average temperature of the plates is within $\pm 0.2{ }^{\circ} \mathrm{C}$ of the set-point values and the results of two successive measures of the thermal flux meter show a variability constrained within the range of $2 \%$.

The measurement takes place after putting the sample between the two plates with the chamber open, successively closing the stack. The upper plate remains fixed, while the lower one moves up and down due to four independently controlled stepping motors, keeping the position of the sample constant on the lower plate; it is in fact controlled by four digital thickness sensors, which ensure the correct placement of each corner of the sample.

The average thickness of the sample is determined within $\pm 0.025 \mathrm{~mm}$ accuracy.

Therefore, the sample thickness measurement is a step of the test procedure, whose scheme is reported in Figure 1.

Thermal conductivity is assessed provided that both the difference of temperature between the plates and the thickness of the sample are known. Once thermal equilibrium is reached, thermal conductivity, $\mathrm{k}$, can be obtained using the following equation:

$$
\mathrm{k}=\mathrm{S}_{\mathrm{cal}}(\mathrm{t}) \times \mathrm{Q} \times \frac{\Delta \mathrm{x}}{\Delta \mathrm{t}}
$$

where: 
- $\mathrm{S}_{\mathrm{cal}}(\mathrm{t})$ is the calibration factor $\left(\mathrm{Wm}^{-2} \mu \mathrm{V}^{-1}\right)$;

- $\mathrm{Q}$ is the measured electric signal from the transducer $(\mu \mathrm{V})$;

- $\Delta \mathrm{x}$ is the sample thickness $(\mathrm{m})$;

- $\Delta \mathrm{t}$ is the difference in temperature between the two plates $\left({ }^{\circ} \mathrm{C}\right)$.

Two separate sets of calibration factors are needed, namely $S_{\text {cal }}^{\text {up }}\left(t_{\text {cal }}\right)$ for the upper plate and $S_{\text {cal }}^{\text {low }}\left(t_{\text {low }}\right)$ for the lower plate. The thermal conductivity calculation using Equation (1) allows for the calculation of the two values $\mathrm{k}_{\mathrm{up}}\left(\mathrm{t}_{\mathrm{up}}\right)$ and $\mathrm{k}_{\text {low }}\left(\mathrm{t}_{\text {low }}\right)$ in correspondence with $\mathrm{S}_{\text {cal }}^{\text {up }}\left(\mathrm{t}_{\text {cal }}\right)$ and $\mathrm{S}_{\text {cal }}^{\text {low }}\left(\mathrm{t}_{\text {low }}\right)$, respectively:

$$
\begin{gathered}
\mathrm{k}_{\text {up }}=\mathrm{S}_{\text {cal }}^{\text {up }}\left(\mathrm{t}_{\text {up }}\right) \times \mathrm{Q}_{\text {up }} \frac{\Delta \mathrm{x}}{\Delta \mathrm{t}} \\
\mathrm{k}_{\text {low }}=\mathrm{S}_{\text {cal }}^{\text {low }}\left(\mathrm{t}_{\text {low }}\right) \times \mathrm{Q}_{\text {low }} \frac{\Delta \mathrm{x}}{\Delta \mathrm{t}}
\end{gathered}
$$

The calibration factors are provided by the instrument's maker for various temperature ranges and stored in the non-volatile memory of the instrument.

In Equations (1) and (2), the correspondent temperatures for the upper and lower plate are shown as $t_{\text {up }}$ and $t_{\text {low. }}$. Having two different thermal conductivities, the average value must be calculated as follows:

$$
\mathrm{k}_{\mathrm{avg}}=\frac{\mathrm{k}_{\mathrm{up}}+\mathrm{k}_{\mathrm{low}}}{2}
$$

The analysis also aimed to study how temperature influences thermal conductivity; although the thermal gradient across the specimens was set to $20^{\circ} \mathrm{C}$-which is within the limits stated by the pertinent technical standard [53] — each measurement run involved several average temperatures. The values chosen here are reported in Table 1, registering respectively the set-point values for both the lower $\left(t_{\text {low }}\right)$ and the upper plate $\left(t_{u p}\right)$ and their average temperature, $t_{\text {avg }}$.

Table 1. Temperature values used for every test run.

\begin{tabular}{cccc}
\hline Range ID & $\mathbf{t}_{\text {low }}\left({ }^{\circ} \mathbf{C}\right)$ & $\mathbf{t}_{\text {up }}\left({ }^{\circ} \mathbf{C}\right)$ & $\mathbf{t}_{\text {avg }}\left({ }^{\circ} \mathbf{C}\right)$ \\
\hline 1 & 0 & 20 & 10 \\
2 & 5 & 25 & 15 \\
3 & 10 & 30 & 20 \\
4 & 15 & 35 & 25 \\
5 & 20 & 40 & 30 \\
\hline
\end{tabular}

\subsection{Selection of the Materials}

To obtain compact samples, a binder is required. Among the possible materials, hydraulic lime NHL 3.5 was chosen due to its lower environmental impact compared to commonly used cements, which require higher quantities of energy for their production [54]. The low impact of hydraulic lime NHL 3.5 derives from its recyclability and biodegradability; moreover, hydraulic lime is capable of absorbing $\mathrm{CO}_{2}$, partially balancing the global emissions produced during the process $[55,56]$.

Another positive aspect of this binder is the possibility of obtaining flexible and breathable final products, removing the excess water, which could erode the natural materials, despite the high strength of the lime.

The selected materials were chosen considering their availability within waste from agricultural processes or commercial and factory activities. The chosen materials are shown in Figure 2 and reported here as follows:

1. desiccated and smashed desiccated platanus acerifolia fruits (Figure 2a,b)

2. triturated cork plugs (Figure 2c)

3. water-soaked cardboard (Figure 2d) 
4. coffee parchment skin, which comes off during the roasting process (Figure 2e)

5. chopped cane stalks (Figure 2f)

6. almond/hazelnut/nut shells (Figure 2g)

7. coconut shells (Figure $2 \mathrm{~h}$ )

8. bean and pea pods (Figure 2i)

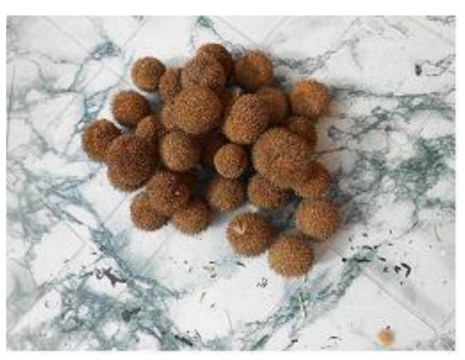

(a)

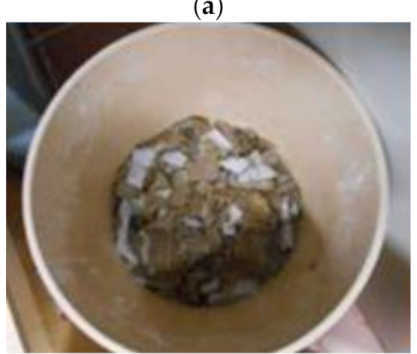

(d)

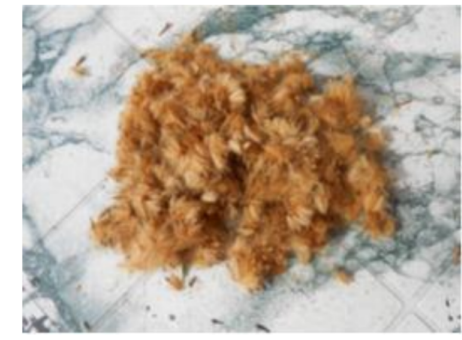

(b)

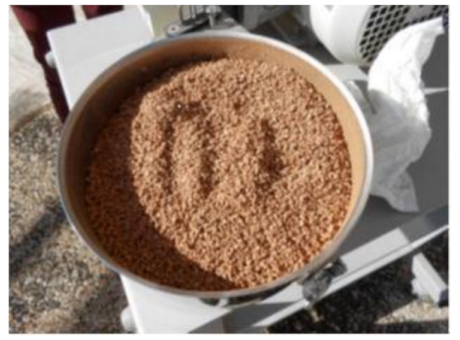

(c)

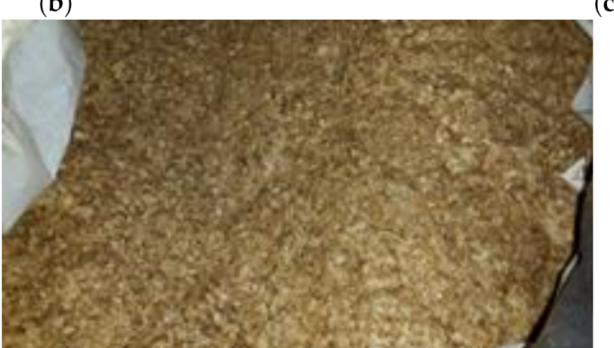

(e)

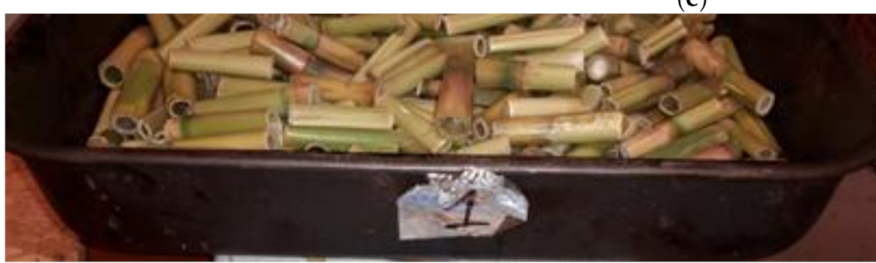

(f)

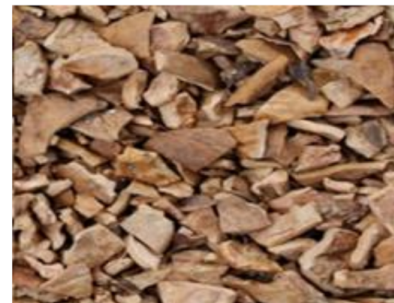

(g)

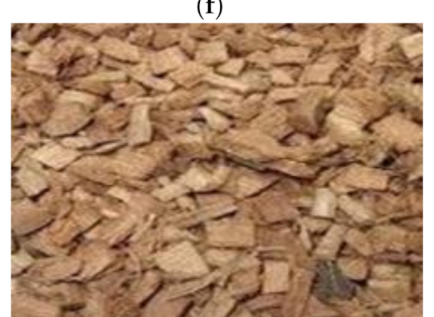

(h)

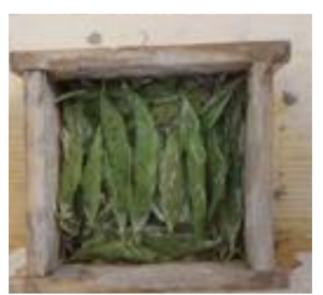

(i).

Figure 2. Natural/waste materials: (a) Desiccated platanus acerifolia fruits; (b) Smashed desiccated platanus acerifolia fruits; (c) Triturated cork plugs; (d) Water-soaked cardboard; (e) Coffee parchment skin; (f); Chopped cane stalks (g) Almond and nut shells; (h) Coconut shells; (i) Bean and pea pods.

The bases for these selections were the cost and the ease of finding these products nearby or in the local market. The platanus acerifolia fruit, for instance, is produced by a tree (i.e., platanus acerifolia or London plane, or hybrid plane), which is a typical roadside plant on the ground that is very tolerant of atmospheric pollution and root compaction. Therefore, it is a diffuse plant in urban contexts. In addition, products such as cork plugs and cardboard from packaging boxes, retrieved before being discarded, are waste materials from commercial activities; coffee parchment skin is discarded by factories; and cane stalks, coconut shells, bean and pea pods, and almond/hazelnut/nut shells derive from the farming sector.

To sum up, the samples studied are all easily retrieved natural materials, cheap and recyclable insulating materials in the building sector. 


\subsection{Preparation of the Specimens}

The selected natural materials were assembled. We obtained nine samples with different mass fractions and thicknesses. In the following sections, the treatment process of each specimen is described.

\subsubsection{Natural/Waste Material Treatment}

Depending on the nature of the selected material, specific pre-treatments were required, to obtain a homogeneous blend of natural material and binder (hydraulic lime and water).

Except for the cane stalks, which were dried in an oven until weight stabilisation was achieved to quickly remove the humidity (also due to the rain) absorbed before they were harvested, all the pre-treatments consisted of processes aimed at reducing the material into pieces to be easily blended into the mixture.

The vegetal/natural materials were also naturally dried to remove humidity (possibly altering thermal conductivity) and make the shredding process easier (e.g., smashed desiccated platanus acerifolia fruits).

To sum up, the pre-treatments were limited to those necessary to blend the materials with the mixture, with the goal of limiting energy consumption and eventually reducing the embodied energy of the final product.

In more detail, as shown in Figure 2, natural materials were treated as follows:

- the platanus acerifolia fruits were naturally desiccated (Figure 2a) and manually mashed (Figure 2b);

- $\quad$ the cork plugs were ground (Figure $2 \mathrm{c}$ ) to obtain particles with a diameter $<2 \mathrm{~mm}$;

- the cardboard was cut into pieces and soaked in water (Figure 2d);

- the cane stalks were dried in an oven at $60^{\circ} \mathrm{C}$ until weight stabilisation, after being chopped in pieces $5 \mathrm{~cm}$ long (Figure 2f).

- the almond and nut shells (Figure 2g) and coconut shells (Figure 2h), were coarsely crushed in pieces with homogeneous dimensions. Likewise, the bean and pea pods (Figure 2i) underwent the same type of process of being naturally dried and homogeneously cut in pieces.

The only material that did not require any treatment was the coffee parchment skin (Figure 2e), composed of the dried skin of coffee beans. In fact, coffee parchment skin is naturally sufficiently dry with a suitable structure, obtained when the husk is removed during the roasting process.

\subsubsection{Preparation of the Mixtures and Construction of the Samples}

Nine samples (A, B, C, D, E, F, G, H, and I in the following) were formed using a wooden parallelepiped framework (Figure 3 ) to keep the sample compact. It has square dimensions $(30 \times 30 \mathrm{~cm})$, as required by the instrument used for investigating thermal properties. The thickness can vary, as shown in Table 2.

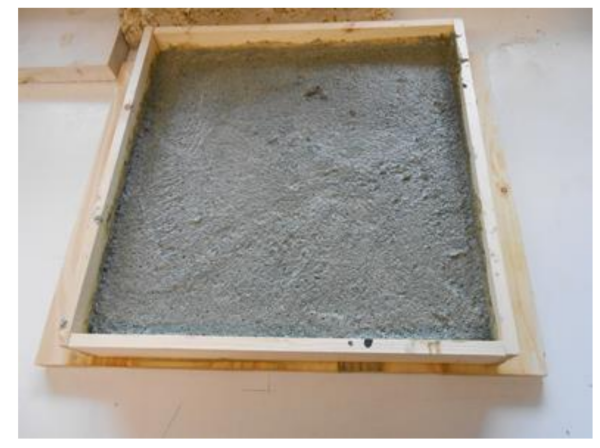

Figure 3. Typical structure of the parallelepiped samples. 
Table 2. Sample structure.

\begin{tabular}{ccccc}
\hline & & & \multicolumn{2}{c}{ Dimension $(\mathbf{c m})$} \\
\hline Sample & Inert Material 1 & Inert Material 2 & Length $\times$ Width & Thickness \\
\hline A & Platanus acerifolia fruits & - & $30 \times 30$ & 4.6 \\
B & Cork plug & - & $30 \times 30$ & 2.9 \\
C & Wet cardboard & - & $30 \times 30$ & 4.4 \\
D & Platanus acerifolia & Wet cardboard & $30 \times 30$ & 4.7 \\
E & Cane Stalks & - & $30 \times 30$ & 3.5 \\
F & Coffee skin & Wet cardboard & $30 \times 30$ & 4.0 \\
G & Coconut shells & Wet cardboard & $30 \times 30$ & 3.1 \\
H & Bean and pea pods & Wet cardboard & $30 \times 30$ & 4.9 \\
I & Almond/hazelnut/nut shells & Wet cardboard & $30 \times 30$ & 5.5 \\
\hline
\end{tabular}

The reasons why the studied samples have different thicknesses are related to a set of factors.

Firstly, considering that both the sample width and length are determined by the instrument chamber size, the thickness of the layer is the only dimension that is allowed to vary. It depends on the quantity of mixture being prepared, which, in turn, depends on the dimensions and amount of inert material available at the time when the experiment was performed (samples B, E and G).

Furthermore, the availability of thinner samples allowed the drying process to be speeded up, with the aim of reducing the duration of the analysis.

Finally, the levelling process, which took place in the formwork, did not keep the final layer thickness under control, given that it was measured by the instrument itself with great accuracy $( \pm 0.025 \mathrm{~mm})$.

In this context, it is also worth noting that test results do not depend on the sample thickness. The rationale for this stems from the definition of thermal conductivity. As a matter of fact, the measured parameter (thermal conductivity) refers to the thickness length unit $\left(\mathrm{Wm}^{-1} \mathrm{~K}^{-1}\right)$.

The unique influence of the sample thickness on the measurements is related to the duration of each test run, because the sample thickness affects the time needed to reach thermal equilibrium.

All the specimens except sample E were constructed by blending a triturated, smashed, or chopped organic/natural material in a natural binder (i.e., hydraulic lime NHL 3.5).

On the contrary, the structure of sample E was obtained by neatly setting the chopped cane stalks between two layers of hydraulic lime mixture, which was also used as a binder for the stalks (Figure 4).

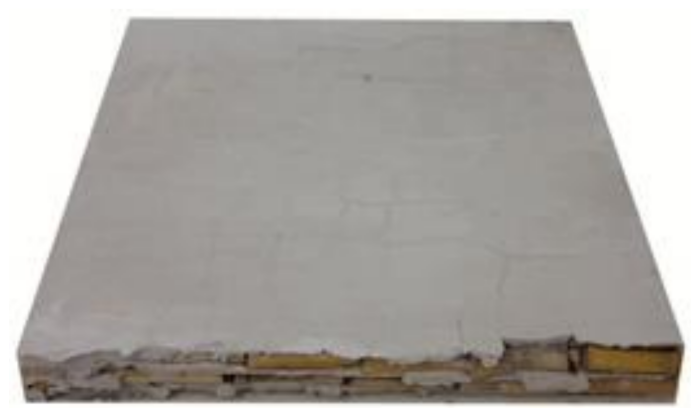

Figure 4. Sample E.

Therefore, the sample was structured as a layered specimen where the stalks constitute the core layer where air is trapped inside each chopped stalk.

Table 3 reports the composition of the different mixtures, and Figure 5 shows how the mass fraction varies in each mixture. 
Table 3. Mixtures' compositions.

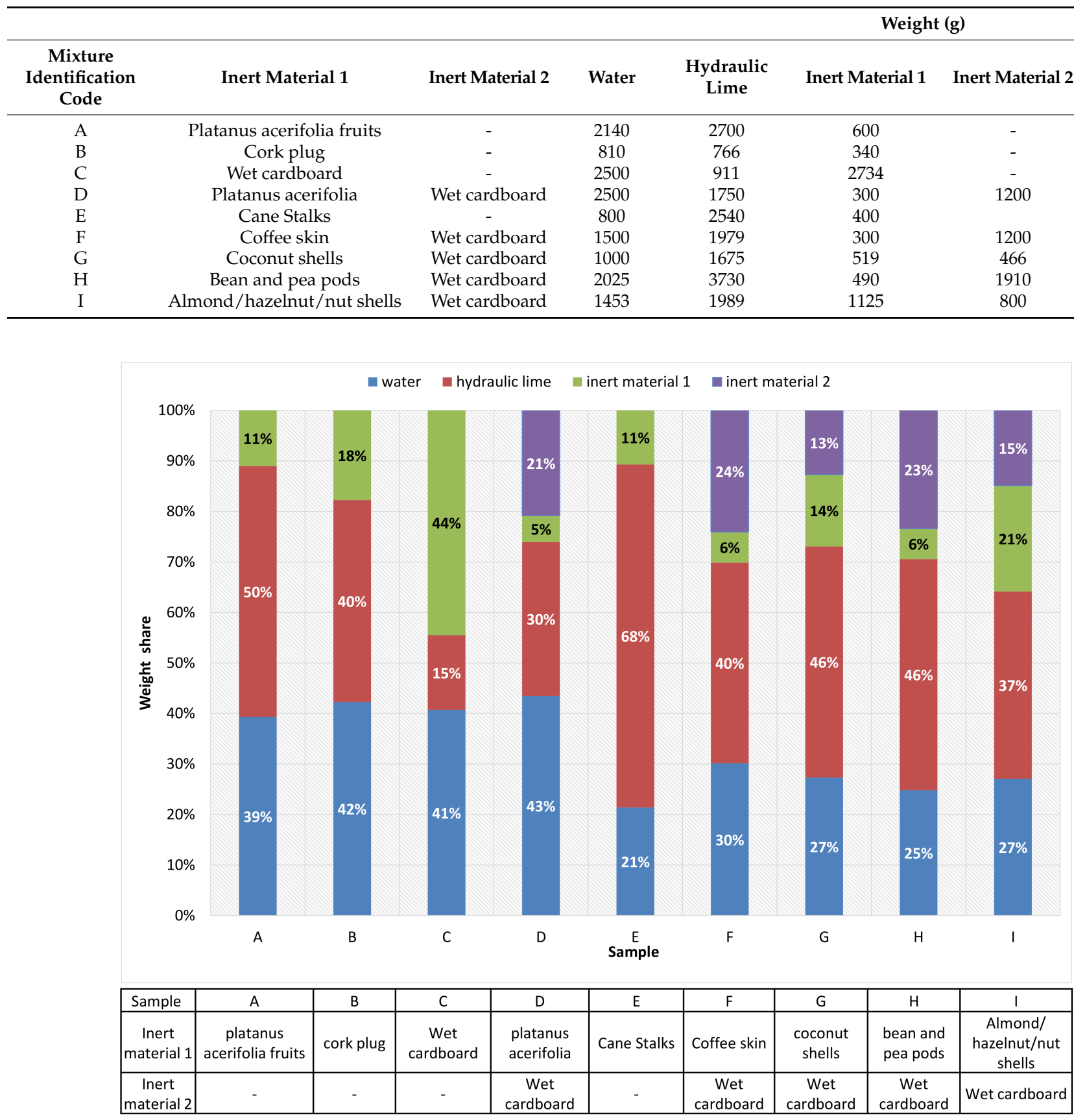

Figure 5. Composition of the studied specimens.

It is worth underlining that in Table 3 and in Figure 5 the water content of the mixture refers only to the quantity needed to meld the hydraulic lime, without considering the water used during the pre-treatments. The water used to dampen the material is instead included in the weight of the wet cardboard (inert material 2).

The content of the binder was varied in order to investigate its influence on the final thermal performance of the sample. As a matter of fact, a greater weight share of the binder could lead to higher thermal conductivity values, and the extent and magnitude of this phenomenon, merit analysis.

This aspect is also important because a higher binder content is needed in order to improve the consistency of the specimen. This is the case of the samples involving thin vegetal fibres (sample A, characterized by a binder weight share of $50 \%$ ) and samples 
with a layered structure (sample E, characterized by a binder weight share of $68 \%$ ). Final conclusions regarding this aspect can be inferred only after the analysis of the mechanical characteristics of the samples, which is planned as a future development of this research.

As far as the water content is concerned, conventional wisdom is that it affects the mixture's workability and its mechanical resistance.

Therefore, the maximum water content was determined with the aim of reaching a workable mixture consistency without compromising its mechanical resistance, allowing the specimens to be smoothed and levelled within the formwork.

Table 3 and Figure 5 also show that samples D, F, G, H, and I are characterized by the presence of two inert materials in the related mixture. In can also be noted that in these cases the second inert material is the cardboard used for packaging boxes, retrieved before being discarded. It was selected as a second inert material for a set of reasons which are also connected to the performances of the studied products, which are detailed below.

In fact, as is better explained in the Results and Discussion section, sample C, where the action of the cardboard was initially tested, was one of the two specimens that showed the best performances in terms of both insulation properties and low density (weight is an important parameter for constructions materials). Therefore, cardboard was used to compose all the other samples in order to try to improve their insulation properties and make them lighter.

Considering the similar performance of sample B (which used cork plug as an inert material), the cork plug could also have been used as a second inert material. However, the cardboard was preferred for its easier pre-treatment process and greater availability. The cork plugs were mechanically ground, whereas the cardboard was simply cut in pieces and soaked in water, creating an amalgam.

To keep the samples stable and maintain their characteristics of homogeneity once assembled, they were kept in the wooden structure for two days. Subsequently, they were weighed for the first time, showing a natural drying process and a consequent weight loss, as shown in Figure 6.

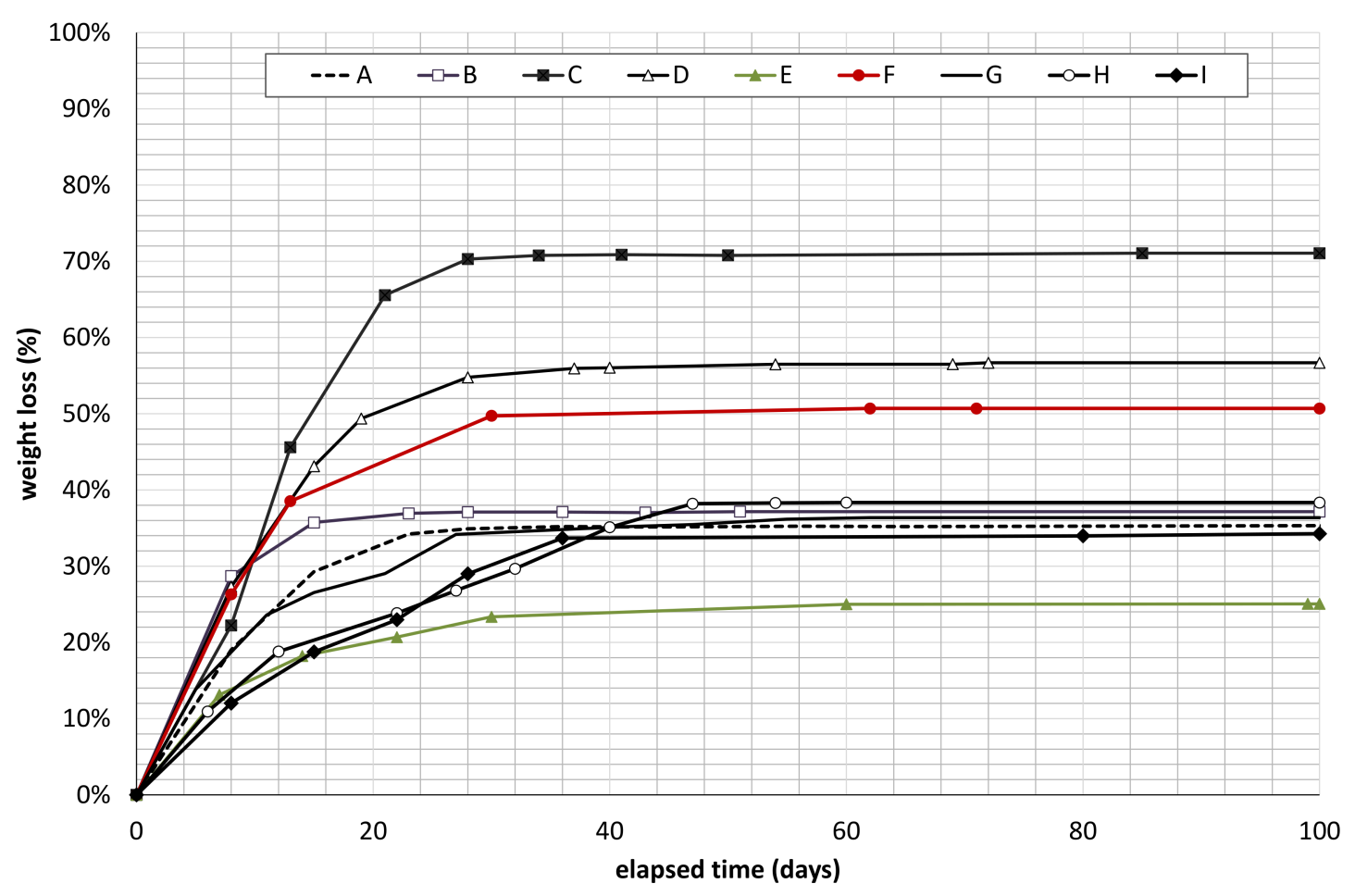

Figure 6. Sample weight loss. The time needed for each sample to stabilise can be inferred.

The curing process of all the specimens occurred in an indoor environment, with natural ventilation and the air temperature fluctuating between $19{ }^{\circ} \mathrm{C}$ and $26^{\circ} \mathrm{C}$. 
The highest weight loss (70\% after 28 days) was registered for sample C. The reasons for this can be ascribed both to its mixture composition, with a lower content of binder, and to the characteristics of the cardboard; in fact, while it initially absorbed a great amount of water, it slowly released it during the drying process.

Considering the first 30 days, samples D and F showed high weight loss values too, as their mixtures were characterized by similar cardboard weight percentages (21\% for sample D and $24 \%$ for F).

Furthermore, comparing the behaviour of these two specimens, it can be inferred that sample D, which has the highest water content in relation to its global weight (43\%), underwent the greatest weight loss (55\% after 28 days).

For specimens G, H, and I lower weight losses were observed, notwithstanding the presence of cardboard among their constituent materials. These results can be ascribed supposedly to the higher hydraulic lime content (between 37\% and $46 \%$ of the total weight) or to the lower water content (between $25 \%$ and $27 \%$ of the total weight) of the mixture.

On the other hand, the lowest weight loss can be observed for sample E, whose layered structure (i.e., a core made of cane stalks confined between two binder layers) entailed a mixture with a high hydraulic lime content and a small amount of water.

In conclusion, Figure 7 reports the density of the samples at the end of the drying process, showing the mass fraction of the solid components of the mixture. Specifically, the drying process was extended up to 100 days before performing the density measurements.

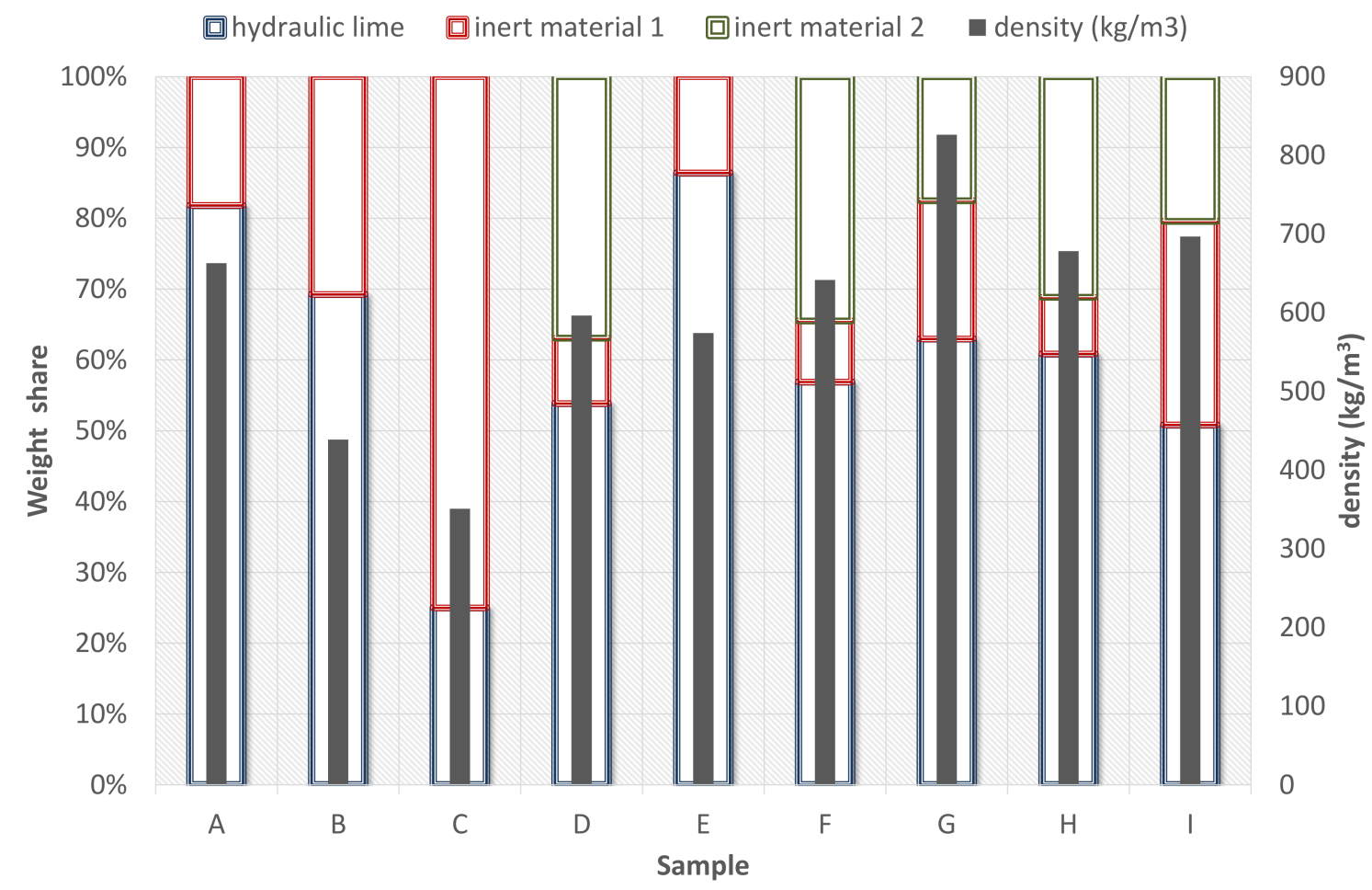

\begin{tabular}{|c|c|c|c|c|c|c|c|c|c|}
\hline Sample & A & B & C & D & E & F & G & H & I \\
\hline $\begin{array}{c}\text { Inert } \\
\text { material 1 }\end{array}$ & $\begin{array}{c}\text { platanus } \\
\text { acerifolia } \\
\text { fruits }\end{array}$ & cork plug & $\begin{array}{c}\text { Wet } \\
\text { cardboard }\end{array}$ & $\begin{array}{c}\text { platanus } \\
\text { acerifolia }\end{array}$ & $\begin{array}{c}\text { Cane } \\
\text { Stalks }\end{array}$ & $\begin{array}{c}\text { Coffee } \\
\text { skin }\end{array}$ & $\begin{array}{c}\text { coconut } \\
\text { shells }\end{array}$ & $\begin{array}{c}\text { bean and } \\
\text { pea pods }\end{array}$ & $\begin{array}{c}\text { Almond/ } \\
\text { hazelnut/nut } \\
\text { shells }\end{array}$ \\
\hline $\begin{array}{c}\text { Inert } \\
\text { material 2 }\end{array}$ & - & - & - & $\begin{array}{c}\text { Wet } \\
\text { cardboard }\end{array}$ & - & $\begin{array}{c}\text { Wet } \\
\text { cardboard }\end{array}$ & $\begin{array}{c}\text { Wet cardboard } \\
\text { cardboard }\end{array}$ & $\begin{array}{c}\text { Wet } \\
\text { cardbot } \\
\text { card }\end{array}$ \\
\hline
\end{tabular}

Figure 7. Density of the studied samples. Density is always lower than $850 \mathrm{~kg} / \mathrm{m}^{3}$.

Conversely to Figure 5, Figure 7 does not consider the weight of the water, referring only to the solid components. 
As underlined in the previous paragraph, the cardboard sample (C) showed the lowest density, because of the combined effects of the remarkable weight loss and of the small lime content.

\section{Results and Discussion}

To carry out thermal conductivity measurements, the samples need to be completely dried, removing all the excess water and thus reaching weight stabilisation. This occurred 30 days after the creation of all the samples, excluding both $\mathrm{H}$ and I, which reached their complete maturation after 45 and 40 days, respectively.

In Figure 8, the main results of this thermal analysis are shown, reporting the correlation between thermal conductivity, $\mathrm{k}$, measured with the instrument and the average temperature during the measurement.

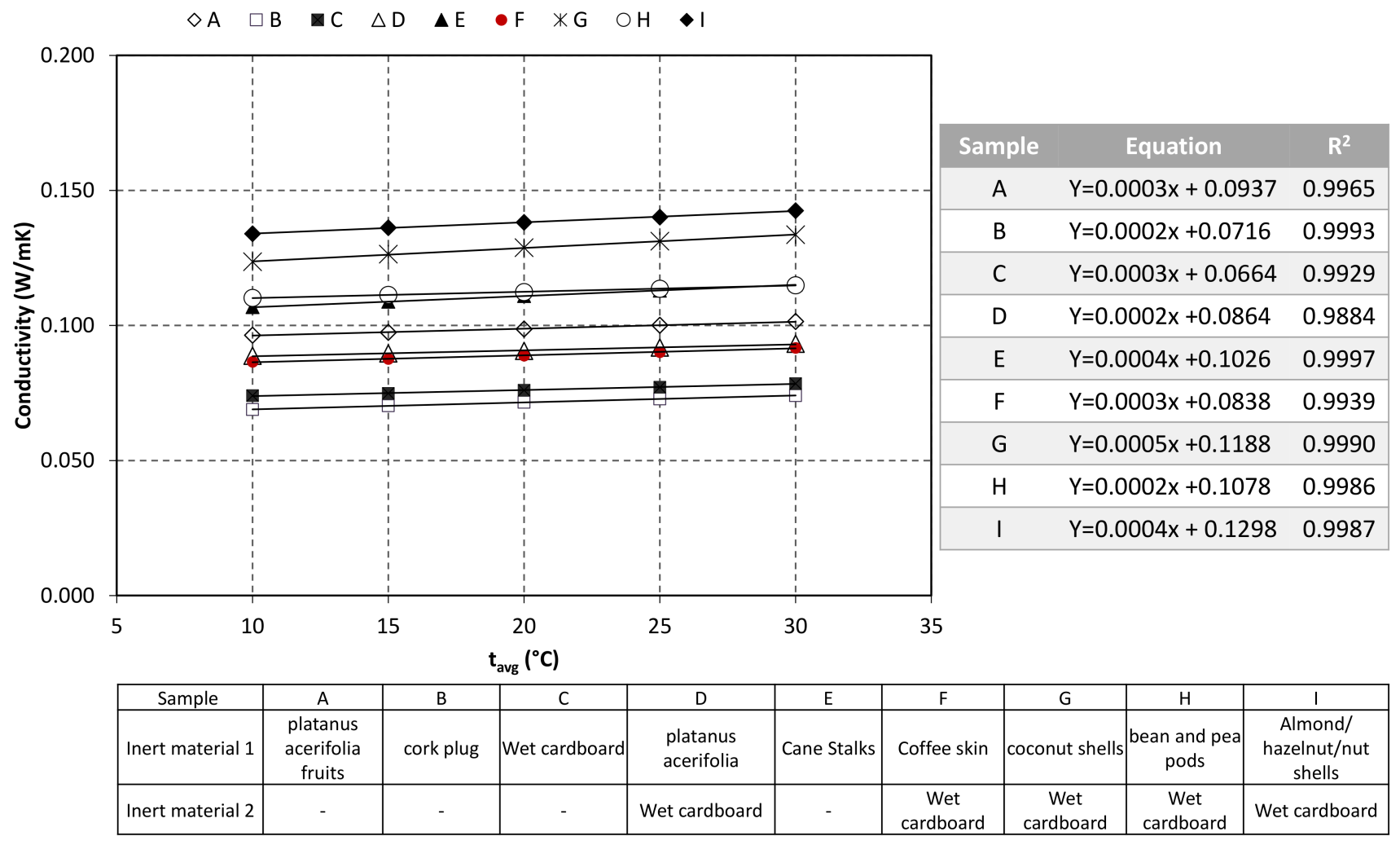

Figure 8. Measurement results. The slight dependence on the average test temperature is appreciable.

It is clear how, for each case, few variations occur in the studied temperature range $\left(0-40^{\circ} \mathrm{C}\right)$, underlining how all these products are perfectly suitable as insulating materials. Table 4 summarizes the results of the measurements in terms of the mean and standard deviation of the thermal conductivity. It varies between a minimum of $0.0715 \mathrm{~W} \mathrm{~m}^{-1} \mathrm{~K}^{-1}$, observed for sample $\mathrm{B}$, thanks to its good insulation properties, to a maximum of $0.1382 \mathrm{~W} \mathrm{~m}^{-1} \mathrm{~K}^{-1}$ for nut shells (sample I), with approximately a double value of $\mathrm{k}$. 
Table 4. Measured thermal conductivity.

\begin{tabular}{|c|c|c|c|c|}
\hline Sample & Inert Material 1 & Inert Material 2 & $\begin{array}{c}\text { Average Value } k \\
\left(\mathrm{~W} \mathrm{~m}^{-1} \mathrm{~K}^{-1}\right)\end{array}$ & $\begin{array}{l}\text { Standard Deviation } \\
\qquad\left(\mathrm{W} \mathrm{m}^{-1} \mathrm{~K}^{-1}\right)\end{array}$ \\
\hline A & Platanus acerifolia fruits & - & 0.0988 & 0.0018 \\
\hline $\mathrm{B}$ & Cork plug & - & 0.0715 & 0.0018 \\
\hline $\mathrm{C}$ & Wet cardboard & - & 0.0761 & 0.0016 \\
\hline $\mathrm{D}$ & Platanus acerifolia fruits & Wet cardboard & 0.0908 & 0.0016 \\
\hline $\mathrm{E}$ & Cane Stalks & - & 0.1109 & 0.0029 \\
\hline $\mathrm{F}$ & Coffee skin & Wet Cardboard & 0.0890 & 0.0018 \\
\hline G & Coconut shells & Wet Cardboard & 0.1287 & 0.0035 \\
\hline $\mathrm{H}$ & Bean and pea pods & Wet Cardboard & 0.1125 & 0.0017 \\
\hline I & Almond/hazelnut/nut shells & Wet Cardboard & 0.1382 & 0.0030 \\
\hline
\end{tabular}

While good results were also obtained for wet cardboard (sample C), probably due to its low hydraulic lime content, coconut shells (sample G) and bean and pea pods (sample H) showed results similar to sample I. Such results can be attributed to the preparation of these samples, where the natural/plant material was not triturated and blended in the mixture but only crushed or cut in pieces, creating a structure with a low porosity and a high compactness, reducing its insulation abilities.

However, it must be also considered that the characteristics of the natural material used as inert materials seem to play a role in this phenomenon. More-fibrous dried vegetal materials (e.g., bean and pea pods-sample $\mathrm{H}$ ) may reduce the insulation properties of the specimen, as the slightly lower thermal conductivity values of sample $\mathrm{H}$ seem to demonstrate.

As regards sample E, which has the layered structure formerly described, where air is trapped inside each chopped cane stalk, it showed less effective thermal insulation properties than those of the more homogeneous specimens (specifically, samples A, B, C, and D).

In this case, it may be supposed that the remarkable content of hydraulic lime ( $86 \%$ of the weight of the solid components-Figure 7), and the specimen's structure with two dense external layers made of a hydraulic lime mixture without lightening materials, could worsen the thermal insulation features of the sample. Furthermore, thermal bridges made of binder might also occur among the chopped stalks and, in addition, air convention phenomena could take place inside the stalks, thus enhancing the heat flow across the slab. However, further investigations are certainly needed on this issue.

All the measurements pertained to one sample for each of the selected and described mixture typologies. This is because the reported analysis was mainly aimed at singling out suitable materials and mixtures. Future and more in-depth analyses are going to be carried out, also taking into account the possible statistical variability of the measurement results when they pertain to various samples coming from the same mixture.

In conclusion, although further in-depth analyses are needed for the actual exploitation of the studied products (also regarding the mechanical properties), the reported results seem to support the suitability of the studied materials for thermal insulation purposes in building construction. Specifically, the materials show proper thermal conductivity values and suitable density features that are similar to most light construction materials (lower than $850 \mathrm{~kg} / \mathrm{m}^{3}$ ) [59].

Low density values are an important feature of construction materials used for nonstructural purposes, because this aspect allows the weight of the building structures to be kept within the stated safety limits.

It is also for this reason that the proposed products might be used as insulating layers within opaque building envelopes (both vertical and horizontal), to be constructed on site (samples A, B, C, D, F, G, H, and I) or pre-assembled (sample E). Depending on the outcome of the analysis regarding the mechanical properties, support structures (e.g., support meshes) might be also needed to sustain and protect the insulation layer. 
The advantages of using the analysed products are related to the possible environmental impacts.

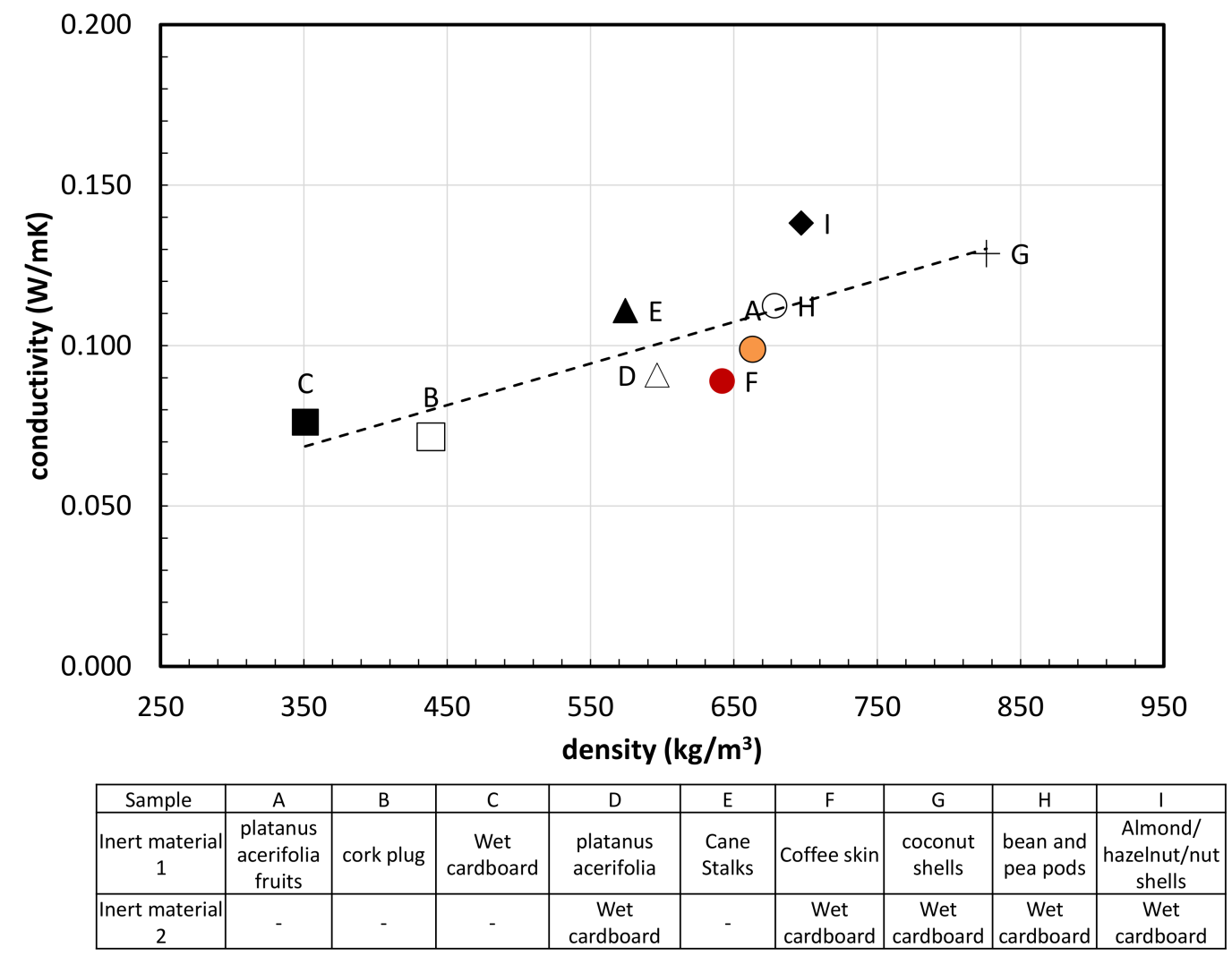

Figure 9. Thermal conductivity versus density.

As a matter of fact, all the materials used to make the specimens are easily retrievable as either the waste of factory/agricultural activities or as the products of plants that usually are located in urban or surrounding areas.

The aim is two-fold: recycling materials that otherwise would have gone to waste, and creating insulation materials that can be made either on site (with constituents retrievable in the construction site areas) or without high-energy-consuming industrial processes.

Therefore, in the mid-long term, the use of these materials in building construction can contribute to both reducing the environmental burden of waste within urban areas and curbing energy consumption due to the production of building materials (with a consequent positive impact on the LCA of edifices).

In addition, the availability of low costs materials with appreciable thermal insulation properties can foster an interest in energy efficiency in the design and creation of building envelopes, making energy-efficient building envelopes sustainable environmentally and economically and promoting the concept of energy efficiency within the building market.

\section{Conclusions}

Nowadays, to reduce pollutant emissions within the building sector and to reach the high standards required for building envelopes, new materials with good insulation abilities and optimal thermo-physical properties have been adopted. Such materials derive from the agricultural, vegetal, or waste sector (waste materials, at a low cost) and for this reason they are sustainable and have a low environmental impact.

In this study, nine different composite structures composed of environmentally friendly materials (i.e., vegetal fibres or waste items derived from farming or commercial/industrial processes) were created and analysed, combining their implicit characteris- 
tics (density, composition, content of water, etc.) together with a commonly used binder of hydraulic lime and water.

Thermal conductivity measurements have been carried out using a heat flow meter.

Almost all the materials underwent pre-treatment (grinding or desiccation, for exam-

ple), to obtain homogeneous samples.

The main results are the following:

- More uniform samples (where the natural/plant material was triturated and blended in the mixture) showed better insulation properties, in particular the ones with light plant/recycled materials (cork, cardboard, and acerifolia fruits) inside.

- Thermal conductivity is strictly influenced by factors such as the composition of the samples (considering the hydraulic lime content) and the final density reached by the samples after the drying process. Thermal conductivity showed a tendency to rise with the final sample density, while lower thermal conductivity values were obtained with lower lime content.

- The average temperature reached during each test run influences the results too. The performed measurements, which were characterized by the same temperature gradient $\left(20^{\circ} \mathrm{C}\right)$, yielded thermal conductivity values that rose slightly with the average temperature of the test, at least for the considered range $\left(10-30^{\circ} \mathrm{C}\right)$.

- Thermal conductivity values for the studied materials vary between a minimum of $0.0715 \mathrm{~W} / \mathrm{m}^{-1} \mathrm{~K}^{-1}$ for cork plugs to a maximum of $0.1382 \mathrm{~W} / \mathrm{m}^{-1} \mathrm{~K}^{-1}$ for nut shells, confirming that the selected materials can be considered a feasible alternative to commonly used materials for insulation in buildings.

The environmental benefits must be considered when talking about such materials: primarily, their use helps reduce the use of widespread materials (synthetic ones for example) with lower conductivity values but a higher global cost, especially in terms of sustainability.

In conclusion, although the results were encouraging in the use of these waste materials, especially regarding the implementation of one of the main pillars of the Industry 4.0 concept (recycling and reduced use of raw materials), further research needs to be carried out to study these materials from a structural point of view, evaluating their mechanical resistance, or analysing how pre-treatment such as drying or the moisture content can influence thermal and mechanical properties.

Author Contributions: The co-authors equally contributed to the completion of this article. Conceptualization, M.L.G., C.M., A.N. and M.P.; data curation, M.L.G., C.M. and M.F.P.; methodology, M.L.G., C.M., A.N., M.F.P. and M.P.; software, A.N. and M.F.P.; supervision, M.P. All authors have read and agreed to the published version of the manuscript.

Funding: This work was carried out within the research project n. 201594LT3F, “La ricerca per i PAES: una piattaforma per le municipalità partecipanti al Patto dei Sindaci (Research for SEAP: a platform for municipalities taking part in the Covenant of Mayors)", which is funded by the PRIN (Programmi di Ricerca Scientifica di Rilevante Interesse Nazionale) of the Italian Ministry of Education, University and Research.

Institutional Review Board Statement: Not applicable.

Informed Consent Statement: Not applicable.

Data Availability Statement: Not applicable.

Conflicts of Interest: The authors declare no conflict of interest. 


\begin{tabular}{lll}
\multicolumn{2}{l}{ Nomenclature } \\
Symbol & Parameter & Unit \\
$\mathrm{k}$ & Thermal conductivity & $\mathrm{Wm}^{-1}{ }^{\circ} \mathrm{C}^{-1}$ \\
$\mathrm{~S}$ & Calibration factor & $\mathrm{Wm}^{-2} \mu \mathrm{V}^{-1}$ \\
$\mathrm{Q}$ & Measured electric signal & $\mu \mathrm{V}$ \\
$\Delta \mathrm{x}$ & Sample thickness & $\mathrm{m}$ \\
$\Delta \mathrm{t}$ & Temperature difference & ${ }^{\circ} \mathrm{C}$ \\
Subscript & Meaning \\
up & Related to the upper plate of the heat flow meter \\
low & Related to the lower plate of the heat flow meter \\
avg & Average
\end{tabular}

\section{References}

1. Yuan, R.; Rodrigues, J.F.; Wang, J.; Tukker, A.; Behrens, P. A global overview of developments of urban and rural household GHG footprints from 2005 to 2015. Sci. Total Environ. 2022, 806, 150695. [CrossRef]

2. European Commission. Energy Roadmap 2050. 2011. Available online: https:/ / ec.europa.eu/clima/eu-action/climate-strategiestargets/2050-long-term-strategy_it \protect \penalty @M (accessed on 10 April 2021).

3. European Commission. Policy Framework for Climate and Energy in the Period from 2020 to 2030. 2014. Available online: https: / / ec.europa.eu/clima/eu-action/climate-strategies-targets /2030-climate-energy-framework_it \protect \penalty \@M (accessed on 10 April 2021).

4. European Commission. Energy 2020. A Strategy for Competitive, Sustainable and Secure Energy. 2010. Available online: https: / / eur-lex.europa.eu/LexUriServ/LexUriServ.do?uri=COM:2010:0639:FIN:En:PDF (accessed on 10 April 2021).

5. Peri, G.; Rizzo, G. The overall classification of residential buildings: Possible role of tourist EU Ecolabel award scheme. Build. Environ. 2012, 56, 151-161. [CrossRef]

6. Jaillon, L.; Poon, C.-S.; Chan, Y.Y.; Lee, M.W.; Cai, X. Green building rating systems and construction waste in high density urban environment: The case study of Hong Kong. Int. J. Sustain. Constr. Eng. Technol. 2020, 11, 60-76. [CrossRef]

7. Ekström, T.; Sundling, R.; Burke, S.; Harderup, L.-E. Probabilistic risk analysis and building performance simulations-Building design optimisation and quantifying stakeholder consequences. Energy Build. 2021, 252, 111434. [CrossRef]

8. Al-Temeemi, A.-S. Climatic design techniques for reducing cooling energy consumption in Kuwaiti houses. Energy Build. 1995, 23, 41-48. [CrossRef]

9. Susanto, M.E. Water-Insoluble Drug Formulation; CSC Press: Boca Raton, FL, USA, 2019; Volume 53. [CrossRef]

10. European Commission. Communication from the Commission to the European Parliament, the Council, the European Economic and Social Committee and the Committe of the Regions on a Monitoring Framework for the Circular Economy \{SWD(2018) 17 final\}. Strasbourg, 16.1.2018. Available online: https:/ / eur-lex.europa.eu/legal-content/EN/TXT/?uri=COM\%3A2018\%3A29\% 3AFIN (accessed on 10 April 2021).

11. Zhong, R.Y.; Xu, X.; Klotz, E.; Newman, S.T. Intelligent Manufacturing in the Context of Industry 4.0: A Review. Engineering 2017, 3, 616-630. [CrossRef]

12. Zezulka, F.; Marcon, P.; Vesely, I.; Sajdl, O. Industry 4.0-An Introduction in the phenomenon. IFAC-PapersOnLine 2016, 49, 8-12. [CrossRef]

13. Lu, Y. Industry 4.0: A survey on technologies, applications and open research issues. J. Ind. Inf. Integr. 2017, 6, 1-10. [CrossRef]

14. Benfratello, S.; Capitano, C.; Peri, G.; Rizzo, G.; Scaccianoce, G.; Sorrentino, G. Thermal and structural properties of a hemp-lime biocomposite. Constr. Build. Mater. 2013, 48, 745-754. [CrossRef]

15. Yuan, J.; Fang, C.; Chen, Q.; Fei, B. Observing bamboo dimensional change caused by humidity. Constr. Build. Mater. 2021, 309, 124988. [CrossRef]

16. Kusuma, Y. Local wisdom as a sustainable building solution: Bamboo incremental house design concept. J. Appl. Sci. Eng. 2022, 25, 119-127. [CrossRef]

17. Fedorik, F.; Zach, J.; Lehto, M.; Kymäläinen, H.R.; Kuisma, R.; Jallinoja, M.; Illikainen, K.; Alitalo, S. Hygrothermal properties of advanced bio-based insulation materials. Energy Build. 2021, 253, 111528. [CrossRef]

18. Yap, Z.S.; Khalid, N.H.A.; Haron, Z.; Mohamed, A.; Tahir, M.M.; Hasyim, S.; Saggaff, A. Waste Mineral Wool and Its Opportunities-A Review. Materials 2021, 14, 5777. [CrossRef]

19. Lianto, F.; Husin, D.; Thedyardi, C.; Choandi, M.; Trisno, R. A retrospective towards a biodegradable material concept for future Indonesian sustainable architecture. City Territ. Arch. 2021, 8, 1-12. [CrossRef]

20. Baccilieri, F.; Bornino, R.; Fotia, A.; Marino, C.; Nucara, A.F.; Pietrafesa, M. Experimental measurements of the thermal conductivity of insulant elements made of natural materials: Preliminary results. Int. J. Heat Technol. 2016, 34, 413-419. [CrossRef]

21. Jiang, D.; Lv, S.; Cui, S.; Sun, S.; Song, X.; He, S.; Zhang, J.; An, P. Effect of thermal insulation components on physical and mechanical properties of plant fibre composite thermal insulation mortar. J. Mater. Res. Technol. 2020, 9, 12996-13013. [CrossRef]

22. Kymalainen, H.R.; Sjoberg, A.M. Flax and hemp fibres as raw materials for thermal insulations. Build. Environ. 2008, 43, 1261-1269. [CrossRef] 
23. Paiva, A.; Pereira, S.; Briga-Sá, A.; Cruz, D.; Varum, H.; Pinto, J. A contribution to the thermal insulation performance characterization of corn cob particleboards. Energy Build. 2012, 45, 274-279. [CrossRef]

24. La Gennusa, M.; Llorach-Massana, P.; Montero, J.I.; Peña, F.J.; Rieradevall, J.; Ferrante, P.; Scaccianoce, G.; Sorrentino, G. Composite Building Materials: Thermal and Mechanical Performances of Samples Realized with Hay and Natural Resins. Sustainability 2017, 9, 373. [CrossRef]

25. Augaitis, N.; Vaitkus, S.; Członka, S.; Kairytè, A. Research of Wood Waste as a Potential Filler for Loose-Fill Building Insulation: Appropriate Selection and Incorporation into Polyurethane Biocomposite Foams. Materials 2020, 13, 5336. [CrossRef]

26. Stonys, R.; Kuznetsov, D.; Krasnikovs, A.; Škamat, J.; Baltakys, K.; Antonovič, V.; Černašejus, O. Reuse of ultrafine mineral wool production waste in the manufacture of refractory concrete. J. Environ. Manag. 2016, 176, 149-156. [CrossRef] [PubMed]

27. U.S. Green Building Council, LEED (Leadership in Energy and Environmental Design). 2017. Available online: http://www. usgbc.org/ (accessed on 10 April 2021).

28. Building Research Establishment, BREEAM (Building Research Establishment Environmental Assessment Method). 2017. Available online: https:/ / www.breeam.com/ (accessed on 28 July 2021).

29. EU. Directive 2010/31/EU of The European Parliament and of the Council of 19 May 2010 on the Energy Performance of Buildings (Recast). 2010. Available online: http:/ / eur-lex.europa.eu/LexUriServ/LexUriServ.do?uri=OJ:L:2010:153:0013:0035:EN:PDF (accessed on 10 April 2021).

30. Yu, H.; Zhang, H.; Zhao, J.; Liu, J.; Xia, X.; Wu, X. Thermal conductivity of micro/nano-porous polymers: Prediction models and applications. Front. Phys. 2022, 17, 23202. [CrossRef]

31. Courtois, E.; Glouannec, P.; Magueresse, A.; Loulou, T. Estimating thermal properties of phase change material from heat flux measurements. Int. J. Therm. Sci. 2022, 172, 107307. [CrossRef]

32. Marino, C.; Nucara, A.; Pietrafesa, M. Mapping of the indoor comfort conditions considering the effect of solar radiation. Sol. Energy 2015, 113, 63-77. [CrossRef]

33. Decorte, Y.; Steeman, M.; Bossche, N.V.D. Effect of a one-dimensional approach in LCA on the environmental life cycle impact of buildings: Multi-family case study in Flanders. Build. Environ. 2021, 206, 108381. [CrossRef]

34. Castell, A.; Menoufi, K.; de Gracia, A.; Rincón, L.; Boer, D.; Cabeza, L.F. Life Cycle Assessment of alveolar brick construction system incorporating phase change materials (PCMs). Appl. Energy 2013, 101, 600-608. [CrossRef]

35. Peng, C.; Kim, Y.J.; Zhang, J. Thermal and energy characteristics of composite structural insulated panels consisting of glass fiber reinforced polymer and cementitious materials. J. Build. Eng. 2021, 43, 102483. [CrossRef]

36. Karami, P.; Al-Ayish, N.; Gudmundsson, K. A comparative study of the environmental impact of Swedish residential buildings with vacuum insulation panels. Energy Build. 2015, 109, 183-194. [CrossRef]

37. Aranda-Usón, A.; Ferreira, G.; López-Sabirón, A.M.; Mainar-Toledo, M.; Bribián, I.Z. Phase change material applications in buildings: An environmental assessment for some Spanish climate severities. Sci. Total Environ. 2013, 444, 16-25. [CrossRef]

38. Ji, S.; Lee, B.; Yi, M.Y. Building life-span prediction for life cycle assessment and life cycle cost using machine learning: A big data approach. Build. Environ. 2021, 205, 108267. [CrossRef]

39. Corscadden, K.; Biggs, J.; Stiles, D. Sheep's wool insulation: A sustainable alternative use for a renewable resource? Resour. Conserv. Recycl. 2014, 86, 9-15. [CrossRef]

40. Zach, J.; Hroudová, J.; Brožovský, J.; Krejza, Z.; Gailius, A. Development of Thermal Insulating Materials on Natural Base for Thermal Insulation Systems. Procedia Eng. 2013, 57, 1288-1294. [CrossRef]

41. Sutcu, M.; Ozturk, S.; Yalamac, E.; Gencel, O. Effect of olive mill waste addition on the properties of porous fired clay bricks using Taguchi method. J. Environ. Manag. 2016, 181, 185-192. [CrossRef] [PubMed]

42. Tian, J.; Yang, Y.; Xue, T.; Chao, G.; Fan, W.; Liu, T. Highly flexible and compressible polyimide/silica aerogels with integrated double network for thermal insulation and fire-retardancy. J. Mater. Sci. Technol. 2022, 105, 194-202. [CrossRef]

43. Tokbolat, S.; Nazipov, F.; Kim, J.R.; Karaca, F. Evaluation of the Environmental Performance of Residential Building Envelope Components. Energies 2019, 13, 174. [CrossRef]

44. Rocchi, L.; Kadziński, M.; Menconi, M.; Grohmann, D.; Miebs, G.; Paolotti, L.; Boggia, A. Sustainability evaluation of retrofitting solutions for rural buildings through life cycle approach and multi-criteria analysis. Energy Build. 2018, 173, 281-290. [CrossRef]

45. Meng, X.; Luo, T.; Gao, Y.; Zhang, L.; Shen, Q.; Long, E. A new simple method to measure wall thermal transmittance in situ and its adaptability analysis. Appl. Therm. Eng. 2017, 122, 747-757. [CrossRef]

46. Evangelisti, L.; Vollaro, R.D.L.; Asdrubali, F. On the equivalent thermo-physical properties for modeling building walls with unknown stratigraphy. Energy 2022, 238, 121679. [CrossRef]

47. Gori, F.; Corasaniti, S. Experimental Measurements and Theoretical Prediction of the Thermal Conductivity of Two- and Three-Phase Water/Olivine Systems. Int. J. Thermophys. 2003, 24, 1339-1353. [CrossRef]

48. Liu, H.; Tian, Y.; Jiao, J.; Wu, X.; Li, Z. Thermal conductivity modeling of hollow fiber-based porous structures for thermal insulation applications. J. Non-Cryst. Solids 2022, 575, 121188. [CrossRef]

49. Gori, F.; Pietrafesa, M. On the construction method of thermal probes for the measurement of thermal properties of insulating materials. Am. Soc. Mech. Eng. Heat Transf. Div. HTD 1991, 179, 83-89.

50. ASTM. ASTM C518-17. Standard Test. Method for Steady-State Thermal Transmission Properties by Means of the Heat Flow Meter Apparatus; ASTM: West Conshohocken, PA, USA, 2017. 
51. UNI. UNI EN 12667-Thermal Performance of Building Materials and Products-Determination of Thermal Resistance by Means of Guarded Hot Plate and Heat Flow Meter Methods_-Products of High. and Medium Thermal Resistance, Management; UNI-PEnte Nazionale Italiano di Unificazione: Milan, Italy, 2002.

52. British Geological Survey. Natural Hydraulic Limes. 2005. Available online: https://www.bgs.ac.uk/search/home.html?q= Natural+hydraulic+limes\&qSearchBtn $=+$ (accessed on 18 August 2020).

53. Grist, E.R.; Paine, K.A.; Heath, A.; Norman, J.; Pinder, H. The environmental credentials of hydraulic lime-pozzolan concretes. J. Clean. Prod. 2015, 93, 26-37. [CrossRef]

54. Brás, A.; Faria, P. Effectiveness of mortars composition on the embodied carbon long-term impact. Energy Build. 2017, 154, 523-528. [CrossRef]

55. Koçyiğit, F.; Ünal, F.; Koçyiğit, S. Experimental analysis and modeling of the thermal conductivities for a novel building material providing environmental transformation. Energy Sources Part. A Recovery Util. Environ. Eff. 2020, 42, 3063-3079. [CrossRef]

56. Korjenic, A.; Zach, J.; Hroudová, J. The use of insulating materials based on natural fibers in combination with plant facades in building constructions. Energy Build. 2016, 116, 45-58. [CrossRef]

57. Davraz, M.; Koru, M.; Akdağ, A.E. The Effect of Physical Properties on Thermal Conductivity of Lightweight Aggregate. Procedia Earth Planet. Sci. 2015, 15, 85-92. [CrossRef]

58. Nagy, B.; Nehme, S.G.; Szagri, D. Thermal Properties and Modeling of Fiber Reinforced Concretes. Energy Procedia 2015, 78, 2742-2747. [CrossRef]

59. Iyer, N.R. An Overview of Cementitious Construction Materials; Elsevier: Amsterdam, The Netherlands, 2020 ; pp. 1-64. 